Canadian Journal of Higher Education

Revue canadienne d'enseignement supérieur

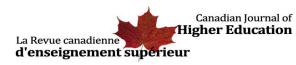

\title{
Faculty Associations Confront Accountability Governance in Ontario Universities
}

\section{Michelle Webber et Jonah Butovsky}

Volume 48, numéro 3, 2018

URI : https://id.erudit.org/iderudit/1057134ar

DOI : https://doi.org/10.7202/1057134ar

Aller au sommaire du numéro

\section{Éditeur(s)}

Canadian Society for the Study of Higher Education

\section{ISSN}

2293-6602 (numérique)

Découvrir la revue

\section{Citer cet article}

Webber, M. \& Butovsky, J. (2018). Faculty Associations Confront Accountability Governance in Ontario Universities. Canadian Journal of Higher Education / Revue canadienne d'enseignement supérieur, 48(3), 165-181.

https://doi.org/10.7202/1057134ar

\section{Résumé de l'article}

De nombreuses recherches sur l'université étudient la propagation du néo-libéralisme dans le milieu universitaire en général. Nous soutenons que les universités canadiennes opèrent sous un régime de " gestion responsable " avec des idéologies, des discours et des pratiques centrés sur la qualité, l'imputabilité et l'efficacité et nous analysons les effets des régimes de gestion actuels sur le corps professoral universitaire ontarien et sur les façons dont leurs syndicats résistent à l'empiétement de leur autonomie professionnelle. À partir d'entrevues qualitatives avec des dirigeants de plusieurs associations de professeurs universitaires ontariens, nous explorons les thèmes de la néo-libéralisation et de la corporatisation de l'université, de la réduction des budgets, des révisions de programme et des mandats stratégiques. Alors que des possibilités d'actions et de résistance, particulièrement au Sénat, se présentent aux syndicats, plusieurs membres ne sont pas favorables à une augmentation du militantisme et du radicalisme, considérant souvent l'action politique comme «non professionnelle ». 
Canadian Journal of Higher Education Revue canadienne d'enseignement supérieur

Volume 48, No. 3, 2018, pages $165-181$

\title{
Faculty Associations Confront Accountability Governance in Ontario Universities
}

\author{
Michelle Webber, Jonah Butovsky
}

Brock University

\begin{abstract}
Much literature focusing on the academy is concerned with the spread of neoliberalism into the university sector. We argue that universities in Canada are operating in an era of "accountability governance," with ideologies, discourses, and practices centred on quality, accountability, and efficiency. We explore the interplay between accountability governance as a regime of power and the work of faculty associations, especially as they strive to preserve faculty members' professional autonomy and control over their academic work. Using in-depth qualitative interviews with executive members of several Ontario university faculty associations, we explore themes of neo-liberalization and corporatization of the university, shrinking faculty budgets, program reviews, and strategic mandates. While opportunities for action and resistance for faculty unions arise, particularly at the level of senate, more militancy and radicalism are not favoured by many members, as political action is often seen as "unprofessional."
\end{abstract}

\section{Résumés}

De nombreuses recherches sur l'université étudient la propagation du néolibéralisme dans le milieu universitaire en général. Nous soutenons que les universités canadiennes opèrent sous un régime de "gestion responsable» avec des idéologies, des discours et des pratiques centrés sur la qualité, l'imputabilité et l'efficacité et nous analysons les effets des régimes de gestion actuels sur le corps professoral universitaire ontarien et sur les façons dont leurs syndicats résistent à l'empiétement de leur autonomie professionnelle. À partir d'entrevues qualitatives avec des dirigeants de plusieurs associations 
de professeurs universitaires ontariens, nous explorons les thèmes de la néo-libéralisation et de la corporatisation de l'université, de la réduction des budgets, des révisions de programme et des mandats stratégiques. Alors que des possibilités d'actions et de résistance, particulièrement au Sénat, se présentent aux syndicats, plusieurs membres ne sont pas favorables à une augmentation du militantisme et du radicalisme, considérant souvent l'action politique comme «non professionnelle».

\section{Introduction}

Much literature focusing on the academy is concerned with the spread of neo-liberalism into the university sector. Many terms and phrases are used to characterize practices of contemporary universities-new managerialism, quality assurance, accountability, performativity, knowledge economy, corporatization, and so forth. Universities are increasingly finding themselves under greater state control while simultaneously seeing declines in state funding. Governments increasingly expect universities to generate private sources of income and to operate along the lines of business values-focusing on "efficiency" and "cost reductions" (Acker \& Webber, 2016; Brownlee, 2016; Deem, Hillyard, \& Reed, 2007; Morley, 2016; Slaughter \& Rhoades, 2000; Tuchman, 2009; Waring, 2014; Webber \& Acker, 2014). We argue that an accountability governance framework is in place in Canadian universities-one in which there is a "set of ideologies and practices linked with the promotion of discourses of quality, accountability, economy, efficiency and enterprise in post-secondary education" (Webber \& Acker, 2012, p. 3). We explore the ways that faculty unions in Ontario, Canada, attempt to resist both the encroachments on their professional autonomy and the shifts that weaken educational quality.

The conversation about accountability governance within higher education is dominated by researchers in Australia, New Zealand, and the United Kingdom. Central government directives create the accountability mechanisms in these countries, at times bringing with them significant financial consequences (Acker \& Webber, 2016; Blachmore \& Sachs, 2003; Deem, 2001; Fitzgerald, White \& Gunter, 2012; Gunter, 2012; Henkel, 2007; Middleton, 2006; Morley, 2005; Shore, 2010; Watson, 2011; Willmott, 2003). While specific accountability governance practices vary by place, researchers identify the 1980 as the starting point for governments turning a more evaluative focus toward their public servants (Stensaker \& Harvey, 2011; Zumeta, 2011). Moving away from their tradition of internal regulation, universities were being expected to provide external reports concerning their performance, thereby creating the need to hire at the administrative levels in order to meet reporting requirements. While accountability, as a general principle, may be difficult to criticize (Zumeta, 2011, p. 10), we can examine its effects.

Canada does not have a federal department of education, which sets us apart from other industrialized countries (Huisman \& Currie, 2004; Shanahan \& Jones, 2007). Canadian universities enjoy high levels of institutional autonomy (Fisher \& Rubenson, 1998). Higher education policies arise at the provincial levels, requiring compliance from individual universities. A high rate of unionization among full-time, permanent Canadian faculty members offers a legal structure of support for resistance against intrusions on academic autonomy (Acker \& Webber, 2016; Dobbie \& Robinson, 2008; Jones, 2013; Webber \& Acker, 2012). 
While Canada may differ from other countries (we have no national research assessment system), faculty members are nonetheless frequently subjected to reviews and assessments of their academic work (research, teaching, and service) through mechanisms such as annual reports, probationary reviews, research funding applications, and tenure and promotion reviews. While these academic assessment practices predate neo-liberalism, rising work expectations and the need to demonstrate one's worth (performativity), features of neo-liberal universities, are certainly present in these assessments (Acker \& Webber, 2016, 2017). Faculty unions, and other unions representing workers in higher education, are critical players in the struggle to defend quality education, academic freedom, collegial governance, as well as the protection of secure employment in universities (Butovsky, Savage, \& Webber, 2013).

In Ontario specifically, following the onset of the "great recession" of 2008, the Liberal government imposed austerity measures on the public sector with the stated aim of easing the fiscal crisis. Funding to Ontario universities had already been the lowest perstudent funding in Canada for two decades (Canadian Association of University Teachers [CAUT], 2012). In 2010, funding for Ontario universities was $24 \%$ below the national average (CAUT, 2011). The Liberal government at that time directed public and para-public sector employers to negotiate settlements with unionized employees that contained two-year wage freezes. This directive was ultimately hindered by an arbitrator's ruling that concluded such a wage-freeze needed to be legislated; the legislation never materialized. In March 2011, the Commission on the Reform of Ontario's Public Services was established with a mandate to recommend ways to reduce spending and strategies for the elimination of the provincial deficit. Former TD Bank chief economist, Donald Drummond, headed the commission whose purpose appeared to be to serve the government's agenda to impose austerity measures on the public sector (Cohn, 2012). The eventual concluding report of the commission, known as the Drummond Report, called for immense cuts to both public spending and services. Analysis of the final report by the Ontario Confederation of University Faculty Associations (OCUFA; 2012) stated that Drummond was "counting on the devastating size of his cuts to the funding of public services to force the parties to bargain concessionary agreements, eliminate jobs, and find 'efficiencies,' which obviously can only translate into dramatically higher workloads for the remaining public sector workers" ( p. 3).

Research on university faculty unions in both Canada and the United States tends to focus primarily on certification drives and organizational capacities (Anderson \& Jones, 1998; Bentham, 2002; Dixon, Tope, \& Van Dyke, 2008; Kniffin, 2011; Rastin, 2000; Savage, Webber, \& Butovsky, 2012), the benefits of collective bargaining, including wages (Martinello, 2009), the relationship of full-time faculty to their universities (Brown, 2003), the impact of unionization on university governance (Horn, 1994; Penner, 1994), and union activism (Fiorito, Tope, Steinberg, Padavic, \& Murphy, 2011; Goldey, Swank, Hardesty, \& Swain, 2010). While these areas have received attention and study, the impact of the current trend of accountability governance on them has received little examination. A notable exception is Gary Rhoades's (2017) work from the United States that analyzes the collective agreement provisions addressing professional rights for contingent faculty on the one hand and managerial discretion on the other hand and whether these contractual provisions go beyond simply addressing wages, while also addressing respect for contingent workers and educational quality. 
Faculty unions represent professional workers. Sociological literature points to professionals as being distinguished by advanced educational requirements and dedicated skills and as enjoying social and occupational prestige (Freidson, 1994; Ritzer \& Walczak, 1986), although the term is a contested one (Evetts 2009a, 2009b; Muzio, Kirkpatrick, \& Kipling, 2011; Savage \& Webber, 2013). Professional unions historically tended to take a different approach than their industrial union counterparts; their histories are not typically rooted in "blood, sweat, and tears." Professional unions are characterized as preferring "conciliation over confrontation at the bargaining table" (Savage \& Webber, 2013, p. 116).

Our exploration of faculty associations and accountability governance is rooted in the work of Michel Foucault. A Foucauldian approach helps us understand regulatory systems (e.g., accountability agreements with government, tenure, and promotion reviews, etc.) as mechanisms of surveillance that promote homogeneity, self-regulation, and conformity (Foucault, 1973, 1980). In the university context, accountability governance as a discourse is "a potent force of surveillance and normalization" (Morley, 2005, p. 411). How we come to identify "good academics" is discursively produced and changes over time with current constructions that include measurable indicators linked to "productivity" (Morley, 2016; Ozga, 2008). When deployed by faculty, faculty association representatives, and/or university administrators, such discursive formations can both constrain and produce particular kinds of relations and possibilities for faculty associations, including collective responses to accountability governance.

Our research contributes to the larger conversation of neo-liberalism and higher education. We are interested in the interplay between the discursive formation of accountability governance as a regime of power and the work of faculty associations (especially as they work to preserve faculty control over academic work) to support and/or disrupt that formation. How do faculty associations position themselves and their actions within this discourse? How do they resist (if at all) accountability governance as a regime of power? Are there creative and/or opportunities for faculty associations?

\section{Method}

Data for this paper are drawn from a larger project entitled "Faculty Associations and the Politics of Accountability in Ontario Universities" that explores, through mixed methods, the priorities, strategies, and efficacy of faculty associations as they navigate the contemporary neo-liberal university context. Thus far, our research has considered how satisfied members are with their unions (Butovsky, Savage, \& Webber, 2016), the politics of professional unions (Savage \& Webber, 2013), and a case study of the unionization of one Ontario association (Savage et al., 2012).

Drawing on Berg (2004), we approached this project qualitatively as we were interested in answering how people acting as executive members of faculty associations understand their roles within their unions and their wider universities, how they act in those roles, how they make sense of the current discursive formation of accountability governance operating in their universities, and how they and their associations might respond to such a governance approach. As we wanted to understand the "perceptions of participants," as well as "how participants come to attach certain meanings to phenomena or events" (Berg, 2004, p. 83), we chose conducting interviews as our method.

Our analysis for this paper is based on 10 qualitative, in-depth, semi-structured interviews. Our interviewees are affiliated with five Ontario university faculty associations. 
Nine of the interviewees are faculty executive members and the remaining interviewees are union staff members. The disciplinary backgrounds of the faculty members are varied, spanning departments in the social sciences, humanities, and health fields. Four of the participants are women; six are men. The universities that were included vary by institutional type and can be classified into three main categories: concentrating on undergraduate education (2), providing a broad range of both undergraduate and graduate programs (2), and concentrating on doctoral programs, including medical schools (1). With a larger sample size, analyses could include attention to the nuances between the institutional types.

We used purposive sampling with the intention of interviewing eight to 10 executive members from four to five associations. Email invitations were sent to presidents, vicepresidents, and grievance officers of seven unionized faculty associations-with five associations participating. The associations chosen represented the best utilization of our resources; they were all within driving distance. Eight of the 10 participants were identified through the original email invitations, and they referred the remaining two participants to us for inclusion in this study.

The participants located at those universities concentrating on undergraduate education are Marion, Isaac, Karl, Leanne, Bradley, and Michael. Those participants located at universities with broad programming (both undergraduate and graduate) are Tracy, Charles, and Ingrid. Douglas is from a medical/doctoral university. All names are pseudonyms.

Our work is located in the general interview guide approach (Turner, 2010). Such an approach allows for common areas of information to be covered while still allowing for flexibility within individual interviews. As Kvale and Brinkman (2009) note, interviews produce knowledge through conversation between the interviewee and the interviewer and this social production of knowledge is always contextual. Interviews followed a common schedule such that each one covered similar topic areas. A semi-structured approach allowed the interviewer to ask follow-up questions that were particular to each participant - to co-author the interview. Interviewees were asked about their own roles with their unions, top-of-mind issues in higher education, issues specific to their own members, member engagement, union strategies, and so forth. Each interview lasted between 60 and 120 minutes (averaging 90 minutes). All of the interviews were conducted face-toface by one of the authors. Interviews were digitally voice-recorded.

Interviews were transcribed by a professional transcriptionist. Transcripts were analyzed in a bricolage approach (Kvale \& Brinkmann, 2009) with the aim of gaining an overall understanding of how shifts in higher education in Ontario are playing out on individual campuses and how faculty unions are responding to these shifts. Transcripts were read and coded with broad categories. The authors discussed the potential broad themes emerging from the interviews and then reviewed passages that stood out as significantthat is, as instrumental to understanding faculty association work and the connections between the collection of interviews. We now turn to the data from this set of interviews.

\section{Findings}

We begin our analysis with a view to sketching out the minefield of pressures and issues that are affecting the working conditions of full-time academics in Ontario universities from the perspective of faculty union executive members. While we present these concerns as separate issues, this is for heuristic purposes only as they are intimately connected. 


\section{Neo-Liberalism and Corporatization}

The global literature in this field documents the changing culture and practices of universities as a result of the spread of neo-liberalism (Brownlee, 2016; Deem et al., 2007, Morley, 2016; Olssen, 2016; Slaughter \& Rhoades, 2000; Tuchman, 2009; Waring, 2014; Webber \& Acker, 2014). While it is important to acknowledge that the shape of the effects of neo-liberalism vary by context (country to country, etc.), the overarching view from our participants is that Ontario universities are following these global trends and are operating in thoroughly neo-liberal ways.

In Ontario, we're seeing a lot more government intrusion into post-secondary education both financially, in terms of using funds to direct what's happening at the university...but also in terms of curriculum issues and just general university climate. (Marion)

The corporatization of higher education. This is the imposition of management structures and styles that come out of the private sector that talk about productivity and revenue generation in which people don't have any say. (Charles)

Echoing what we found in the literature, our participants had the sense that Canada's approach was a kinder and gentler one to that of other countries (Fisher \& Rubenson, 1998). While changes are indeed taking place that are pushing us toward a more market-centred approach, these shifts have taken place without "massive reform of the governance of post-secondary education in Canada" (Shanahan \& Jones, 2007, p. 42).

When I came in as vice-president, [University] was in the very, very early stages of getting ready to accommodate itself to neo-liberalism, and it was early enough that I don't think the majority of faculty saw it coming, and because I'm from the States, I had seen it first-hand before I'd come to [University] and when I saw the signs at [University], I immediately started talking about my concerns.....and I would say the majority of the faculty at [University] were asleep at the switch.... And, in fact, when I would raise it in my department meetings, people would say, "That's not possible. This is Canada; we don't do that here.” (Isaac)

We can see the discursive construction of Canada as "safe" in this participant's account of his early days of being a member of his association's executive. Our participant is asserting that because of the assumption that Canadian universities are so different from schools in the U.S. (and elsewhere), faculty were perhaps politically unprepared for the shifts that were beginning to take place in terms of the organization of their scholarly lives and the universities in which they labour. There is certainly evidence that we in Canada are not immune to the global trend of accountability governance in higher education.

\section{Shrinking Budgets}

An outgrowth of the neo-liberal imposition of business values is a desire to cut costs and manage universities more efficiently. As noted earlier, the 2011 Drummond Report in Ontario called for significant cuts to public services and spending. Under the provincial Liberal government, Ontario was in the grips of an austerity agenda for several years. At the level of individual universities, units have and continue to experience budget cuts after budget cuts. 
Everybody's been slashed. Governments keep clawing back money, while at the same time capping tuition fees and the result of that is with inflation and higher enrolments and things, the universities just can't keep up. So where we're seeing the impact at the ground level in the trenches is we are starting to see resources clawed back at a substantial level. (Karl)

Austerity discourses emerged at each of the universities, which were deployed to justify budget cuts in response to budgetary crises. In some institutions, people have faced seven straight years of budget cuts.

I mean the cuts affect all kinds of things from working conditions and lack of maintenance to inadequate travel budgets to inadequate equipment.... [Faculty] experience it also as a kind of nickel-and-diming of things. "What? Didn't I see you take a pack of paper just last week?” This kind of thing. (Tracy)

Faculty members are feeling surveilled to such an extent that the number of pages of printing they do on department printers is being tracked as well as how many packages of paper they use. Union executives are faced with concerned members who feel they do not have the resources to adequately do their jobs to the point that their professional identities are under threat and they are feeling under constant scrutiny (Webber \& Acker, 2014). As Rhoades (2017) argues, the working conditions for faculty matter as the conditions directly connect to the issue of educational quality.

\section{Program Reviews and Strategic Mandate Agreements}

A dominant scenario emerged at several Ontario universities in response to the budgetary environment: program prioritization reviews. Many of our participants reported that a program review process is or was recently active on their campus. To differing degrees, the program prioritization reviews were modelled on Robert Dickeson's (2010) approach to prioritizing academic programs and services (which is also the title of his book). The provincial government encouraged universities to engage in these program reviews through the "Productivity and Innovation Fund" (OCUFA, 2013). Program reviews are a ranking exercise meant to signal what resources university programs ought to receive (socalled high performers) and what programs might be subject to cuts or closure (so-called poor performers). As Craig Heron (2013) notes, though, inappropriate points of comparison are made in Dickeson's (2010) approach when both academic and administrative programs are treated as equivalents in the ranking process. Further, using Dickeson's model attempts to bypass collegial governance mechanisms such as academic senates.

So it's part of a bigger context of both withdrawal of funding, but also of a belief that universities have to identify strengths and weaknesses and use that as justification for cutting costs. (Charles)

Participants identify many of the same flaws noted by Heron (2013) with how these program reviews are being carried out. They identify that academic programs are being assessed in the same way as non-academic services, creating problematic rankings that treat both these areas as equivalent in importance. They point to the problematic way mechanisms, such as program prioritization reviews, evaluate contributions in the acade- 
my. Faculty associations are in a position to question the assumptions made about faculty work and what gets valued within such disciplinary exercises. They are able to communicate to their members how these reviews can be problematic and how their members can intervene to resist processes that attempt to quantify academic worth, limit the breadth of what is considered a scholarly contribution, and potentially reshape the academic landscape in their universities.

So we have templates straight out of the Dickeson book in which everything gets little scores. This is how [University] fetched up with the parking at the top and the English department at the bottom, and how the [Hospital] fetched up with patient care at the bottom.... This is an exercise which is going to demonstrate that parking is really valuable and the Liberal Arts are not. (Ingrid)

What concerns the members right now is a sense of being judged in ways that are not appropriate for academic programs, of being threatened with consequences for reasons that do not originate in reasoned action or valid academic criteria and in which they have had little control or input...and probably the biggest object[ion] that the union has to this program review, is that it is existing independent of senate, and it is senate that should be the body that reviews academic units. (Marion)

Under many collective agreements, faculty members are responsible for long-term academic program planning. Program prioritization reviews aim to remove responsibility for such planning from academics themselves and shift responsibility into the hands of administrators. At one of our universities, faculty members sitting on the senate collectively mobilized and successfully changed the program review process such that it became divided into two evaluation schemes: administrative units and academic programs. Administration remained responsible for evaluating administrative units, but the senate became responsible for the evaluation of academic programs.

At the same time the provincial government demanded Strategic Mandate Agreements (SMAs) from Ontario universities. These agreements will be tied to incentive funding and represent the government's attempt to differentiate universities. These agreements are front and centre in the minds of faculty union representatives.

We are very concerned about that because obviously the [union] had no say in our Strategic Mandate Agreement and what the university may consider to be their position moving forward may be in conflict with our members and what our members are doing right now. So that's a major concern. (Karl)

From the point of view of full-time faculty, people do not feel as though there has been adequate consultation on the construction of the strategic mandate agreements. Senior administrators drafted the agreements and submitted them to the government. Faculty and union executive members worry about what these agreements and their implementation will mean for their individual institutions.

And the problem with the SMAs, as I see it, is the SMAs absolutely are going to impact academic direction and they are absolutely going to have to do with money and that just...you cannot look at them in isolation. They can impact every single aspect of what we are doing. (Leanne) 
All the while, the fall-out from these program reviews and strategic mandates is creating a culture of distrust in relation to the senior administration. There is a sentiment among full-time faculty that the administrations are acting in completely top-down approaches rather than engaging in meaningful collegial governance.

Gradually and incrementally decision-making powers have been leeched away from the lower ranks, the trenches, up into the central administration...and the central administration has become, possibility as a result of that, also extraordinarily bloated. (Ingrid)

At times, I personally am under the impression that these [consultation] processes [are] just a means to justify, try to justify, and try to legitimize decisions that have already been made and not trying to create additional information in order to make better decisions, which I think [is] what mutual consultation should be all about, really. (Douglas)

And yet what senior administrators appear to disregard is that, unlike many other workplaces, the interests of university faculty are often aligned with those of the administration. Faculty want to be part of the decision-making process that will fundamentally affect the quality of education at their universities as well as the conditions under which they work.

I think you'd find a vast majority of faculty members would say that their interests are closely aligned with the interests of the employer or the university. It's providing education, excellence, job training, et cetera. (Michael)

The lack of meaningful consultation and an appearance of decisions that will impact the existence and vitality of academic programs being made ahead of time are leading to cultures of distrust on campuses. Further, with the exception of one association, members of the other four all report increasingly tense and adversarial relationships between their unions and their respective administrations.

They are also less collegial than they used to be. Yeah, and I think that many of our current administrators really misunderstand the collegial workplace. (Tracy)

I think that there is tension between the administration and the Faculty Association. That's just the tip of the iceberg, I think. (Michael)

\section{Opportunities for Action}

Faculty associations can play a pivotal role in disrupting the normalizing tendencies within accountability governance regimes. They are in the position to resist against encroachments to academic freedom, collegial governance, narrowing definitions of academic work and worth, and so forth. The executive members we spoke with all talked about the strategies they are using to resist what is happening at their universities. The most common strategy for resistance is member education-whether it is about program reviews, strategic mandate agreements, and/or budget cuts.

When the results of this play out, and we've done nothing, we will lose any credibility with our membership. And so the whole strategy of producing sharply critical 
communications is something that is not in keeping with a strict, legal defense of the collective agreement, but I thought it was critical, because who else could do this, because as members of the executive, I think that we are protected to some extent.... Essentially you are fighting to convince your own membership that they shouldn't just accept what the administration is doing. (Charles)

We can see Charles begin to raise this notion about what kind of unionism do faculty associations want to practise. Is it a business union approach concerned with the four corners of a collective agreement? Or do they wish to broaden their engagement to a more social unionism approach-one that in the context of higher education advocates for the state of post-secondary education more broadly (Ross, 2011, 2012)?

Our participants spoke of general membership meetings where attaining quorum is difficult. But these program reviews, government intrusions, and budget cuts have provided critical opportunities for resistance by the unions in the accountability governance regime. Members who were not overtly interested in their unions before are now taking notice as encroachments on their professional autonomy continue to unfold.

They were not nuts about the union, but thank you very much, Mr. President of the University, for shoving them into our court against their better judgment, honestly. (Isaac)

Anything that gets faculty members upset or agitated, I love, because it means that the faculty association can sometimes harness that militancy and aim it in different directions. (Michael)

The anger of their members about changes in their universities and threats to their profession are creating pivotal moments of opportunity for resistance for the unions of fulltime faculty. The other arena where unions are attempting to intervene is in their university senates. However, most take note of the divides in thinking that exist as to whether there is a role for "the union" to play in the senate-seemingly forgetting for a moment, of course, that union executive members are also faculty members. Such a discursive construction of what it means to be a professional invokes a notion that professionals do not act politically.

So we engaged, for the first time ever, in attempting to influence the senate which had been off-limits to the union at that point. It was sort of a tacit agreement that the senate was the senate, the union was the union, and, in fact, when I first approached the senate, the chair of the senate said to me, "No, the senate is the senate and the union has no business influencing the senate," which I didn't pay any attention to because I had many members on the senate. (Isaac)

The possibility of mobilizing for collective action is also hampered by divided executives over an understanding of the primary roles of the union. First and foremost, participants identify the union as being responsible for enforcing the four corners of their respective collective agreements. The unions appear to operate as business unions-ones that are concerned with workplace issues (Ross, 2011, 2012). When issues that fall outside of the collective agreement are raised, there is often a tension among executive members as to whether the union has a legitimate role to play. 
It's maybe the activists versus the "what's the contractual problem?" None, obviously, but...so there is that kind of tension. I guess it's personalities, it's different political views. (Tracy)

The idea that the union has to do something or help faculty to regain control of programs and initiatives...there were people on the executive that said in a legalistic way, "We're sympathetic, but what can we do, it's only about enforcing the collective agreement." But other people spoke up...and said, "But this is representative of the fact that our members our saying, 'You're the only ones that speaks for us. And even though that's not your direct role, that's what we care about, that we no longer feel that we have any say in things."' (Charles)

These interview excerpts point to the tensions in the discursive field that some executives are navigating as they actively try to preserve faculty control over academic work and defend against university practices that threaten professional autonomy. Only one of the five faculty associations included in our interviews appears to operate with a more social unionism model (Ross, 2012). This union involves themselves not just with issues affecting their members in the workplace but also with larger sector issues and broader social justice movements.

[We] care about the bread and butter of the workplace, about negotiating good contracts and defending their members, but [we also] have a broader or more solidaristic worldview that [we] think that the union has an important role to play in achieving larger social and economic gains for working-class people in general. (Michael)

Unsurprisingly, this association is the most politically engaged vis-à-vis the broader labour movement, participating in central labour organizations such as the Ontario Federation of Labour and the local labour council, as well as forging ties with other campus unions.

\section{Conclusion}

Neo-liberalism and corporatization have firmly taken root in higher education. Austerity discourses, accountability governance practices, and program prioritization reviews are firm indicators. Faculty associations recognize a crisis is unfolding in front of their eyes, but their strategic responses are not as clear cut. Rather than confining faculty union activity to negotiating wages and benefits, faculty unions are being called upon to advocate more broadly for the health of post-secondary education. Faculty unions are in a position to fight against neo-liberal shifts that encourage conformity, self-surveillance, homogeneity among academics, and how scholarly work is defined and valued. Faculty associations have the potential to mobilize collective resistance to counter the worst elements and effects of accountability governance approaches. As Rhoades (2017) explores with unions representing the new faculty majority in the United States (contingent faculty), unions representing academic workers are in a position where they need to move beyond a business union model to advocate for bread (wages), roses (respect), and quality (of education).

Although the times arguably call for more militancy and radicalism, faculty associations, for the most part, have shied away from that direction (as evidenced by individual 
associations' unwillingness to mount partisan campaigns for political candidates, reluctance to run slates or organize attempts to take over academic senates, and so forth). We argue such reluctance is a product of professional discourse that casts political action as "unprofessional." Sustained militancy can be difficult to achieve with workers who identify as professionals (Savage \& Webber, 2013). However, professionalism is a complicated discourse. The rise of neo-liberal accountability governance fundamentally undermines practices of professional autonomy and meaningful collegial governance within our universities. As we saw with resistance to program prioritization schemes, faculty are asking their unions for action when the threats hit too close to home, directly affecting their academic work and working conditions. Professionalism or professional identity can be harnessed as a tool to mobilize faculty members to collectively resist shifts in our universities around the purpose of the university, the publics they serve, and the professional identity they cherish.

\section{Acknowledgement}

This research was supported in part by SSHRC, Grant \#102874.

\section{References}

Acker, S., \& Webber, M. (2016). Uneasy academic subjectivities in the contemporary Ontario university. In J. Smith, J. Rattray, T. Peseta, \& D. Loads (Eds.), Identity work in the contemporary university: Exploring an uneasy profession (pp. 61-75). Rotterdam, Netherlands: Sense Publishers.

Acker, S., \& Webber, M. (2017). Made to measure: Early career academics in the Canadian university workplace. Higher Education Research and Development, 36(3), 541-554. https://doi.org/10.1080/o7294360.2017.1288704

Anderson, B., \& Jones, G.A. (1998). Organizational capacity and political activities of Canadian university faculty associations. Interchange, 29(4), 439-461.

Bentham, K. (2002). Employer resistance to union certification. Relations Industrielles, 57(1), 159-187. https://www.riir.ulaval.ca/sites/riir.ulaval.ca/files/2002_57-1_10.pdf

Berg, B. (2004). Qualitative research methods for the social sciences (5th ed.). Boston, MA: Pearson.

Blachmore, J., \& Sachs, J. (2003). Managing equity work in the performative university. Australian Feminist Studies, 18(41), 141-162.

Brown, W. (2003). Academic politics: Faculty unions and the academic perception. In J. DeCew (Ed.), Unionization in the academy: Visions and realities (pp. 139-165). Lanham, MD.: Rowman and Littlefield Publishers.

Brownlee, J. (2016). The role of governments in corporatizing Canadian universities. Academic Matters, January, 17-21. https://academicmatters.ca/2016/o1/the-role-ofgovernments-in-corporatizing-canadian-universities/

Butovsky, J., Savage, L., \& Webber, M. (2013, January). Satisfaction with limits: Analyzing the views that Ontario university faculty have of their unions. Paper presented at the Southern Political Science Association Conference, Orlando, FL. 
Butovsky, J., Savage, L., \& Webber, M. (2016). Assessing the potential impact of labor law reforms on university faculty: Findings from a midsized public university. Labor Studies Journal, 41(2), 204-219. https://doi.org/10.1177/0160449X16647531

Canadian Association of University Teachers (CAUT). (2011). CAUT almanac of postsecondary education in Canada 2010-2011. Retrieved from https://www.caut.ca/docs/ default-source/almanac/2010_caut_almanac_en.pdf?sfvrsn=4

Canadian Association of University Teachers (CAUT). (2012). CAUT almanac of postsecondary education in Canada 2011-2012. Retrieved from http://www.caut.ca/docs/ default-source/almanac/almanac-2011-2012.pdf

Cohn, M. R. (2012, March 26). Politics of restraint for an austerity budget. Toronto Star. Retrieved from https://www.thestar.com/news/canada/2012/03/26/cohn_ politics_of_restraint_for_an_austerity_budget.html

Deem, R. (2001). Globalisation, new managerialism, academic capitalism and entrepreneurialism in universities: Is the local dimension still important? Comparative Education, 37(1), 7-20. https://doi.org/10.1080/03050060020020408

Deem, R., Hillyard, S., \& Reed, M. (2007). Knowledge, higher education and the new managerialism: The changing management of UK universities. Oxford, UK: Oxford University Press.

Dickeson, R. (2010). Prioritizing academic programs and services: Reallocating resources to achieve strategic balance. San Francisco, CA: Jossey-Bass.

Dixon, M., Tope, D., \& Van Dyke, N. (2008). "The university works because we do": On the determinants of campus labor organizing in the 1990s. Sociological Perspectives, 51(2), 375-396.

Dobbie, D., \& Robinson, I. (2008). Reorganizing higher education in the United States and Canada: The erosion of tenure and the unionization of contingent faculty. Labour Studies Journal, 33(2), 117-140. https://doi.org/10.1177/0160449X07301241

Evetts, J. (2009a). The management of professionalism: A contemporary paradox. In S. Gewirtz, P. Mahony, I. Hextall, \& A. Cribb (Eds.), Changing teacher professionalism: International trends, challenges and ways forward (pp. 19-30). London, UK: Routledge.

Evetts, J. (2009b). New professionalism and new public management: Changes, continuities and consequences. Comparative Sociology 8, 247-266. doi:10.1163/156913309X421655

Fiorito, J., Tope, D., Steinberg, P., Padavic, I., \& Murphy, C. (2011). Lay activism and activism intentions in a faculty union: An exploratory study. Labor Studies Journal, 36(4), 483-507. doi:10.1177/0160449X11422609.

Fisher, D., \& Rubenson, K. (1998). The changing political economy: The private and public lives of Canadian universities. In J. Currie \& J. Newson (Eds.), Universities and globalization: Critical perspectives (pp. 77-98). Thousand Oaks, CA: Sage.

Fitzgerald, T., White, J., \& Gunter, H. (2012). Hard labour? Academic work and the changing landscape of higher education. Bingley, Engalnd: Emerald. 
Foucault, M. (1973). The birth of the clinic. London, UK: Tavistock.

Foucault, M. (1980). Power/knowledge: Selected interviews and other writings, 1972-1977. Brighton, UK: Harvester.

Freidson, E. (1994). Professionalism reborn: Theory, prophecy, and policy. Chicago, IL: University of Chicago Press.

Goldey, G., Swank, E., Hardesty, C., \& Swain, R. (2010). Union professors: Framing processes, mobilizing structures, and participation in faculty unions. Sociological Inquiry, 8o(3), 331-353. https://doi.org/10.1111/j.1475-682X.2010.00337.x

Gunter, H. (2012). Academic work and performance. In T. Fitzgerald, J. White, \& H. Gunter (Eds.), Hard labour? Academic work and the changing landscape of higher education. International Perspectives on Higher Education Research (Vol. 7, pp. 6585). Bingly, UK: Emerald Group Publishing Limited.

Henkel, M. (2007). Can academic autonomy survive in the knowledge society? A perspective from Britain. Higher Education Research \& Development, 26(1), 87-99. https://doi.org/10.1080/07294360601166836

Heron, C. (2013). Robert Dickeson: Right for Ontario? An analysis of program prioritization. Toronto: OCUFA. Retrieved from https://ocufa.on.ca/assets/DickesonRight-for-Ontario-Craig-Heron.pdf

Horn, M. (1994). Unionization and the Canadian university: Historical and personal observations. Interchange, 25(1), 39-48. doi:https://doi.org/10.1007/BF01447191

Huisman, J., \& Currie, J. (2004). Accountability in higher education: Bridge over troubled water? Higher Education, 48(4), 529-551.

Jones, G. (2013). The horizontal and vertical fragmentation of academic work and the challenge for academic governance and leadership. Asia Pacific Educational Review, 14, 75-83. https://doi.org/10.1007/s12564-013-9251-3

Kniffen, K. 2011. Organizing to organize: the case of a successful long-haul campaign for collective bargaining rights. Labor Studies Journal, 36(3), 333-362.

Kvale, S., \& Brinkmann, S. (2009). Interviews: Learning the craft of qualitative research interviewing. Thousand Oaks, CA: Sage.

Martinello, F. (2009). Faculty salaries in Ontario: Compression, inversion, and the effects of alternate forms of representation. ILR Review, 63(1), 128-145.

Middleton, S. (2006). Researching identities: Impact of the performance-based research fund on the subject(s) of education. In L. Bakker, J. Boston, L. Campbell, \& R. Smyth (Eds.), Evaluating the performance-based research fund: Framing the debate (pp. 489-512). Wellington, NZ: Institute for Policy Studies, Victoria University of Wellington.

Morley, L. (2005). Opportunity or exploitation? Women and quality assurance in higher education. Gender and Education, 17(4), 411-429. https://doi. org/10.1080/09540250500145106

Morley, L. (2016). Troubling intra-actions: Gender, neo-liberalism and research in the global academy. Journal of Education Policy, 31(1), 28-45. https://doi.org/10.1080/o2 680939.2015.1062919 
Muzio, D., Kirkpatrick, I., \& Kipping, M. (2011). Professions, organizations and the state: Applying the sociology of the professions to the case of management consultancy. Current Sociology 59(6), 805-824. https://doi.org/10.1177/0011392111419750

Olssen, M. (2016). Neoliberal competition in higher education today: Research, accountability and impact. British Journal of Sociology of Education, 37(1), 129-148. https://doi.org/10.1080/01425692.2015.1100530

Ontario Confederation of University Faculty Associations (OCUFA). (2012, February 22). OCUFA analysis of the Drummond report: Long on cuts, short on insight. Retrieved from http://ocufa.on.ca/wordpress/assets/OCUFA-Drummond-Report-Analysis-Feb.22-2012Final.pdf

Ontario Confederation of University Faculty Associations (OCUFA). (2013, December 10). Government of Ontario releases differentiation policy framework. Retrieved from http://ocufa.on.ca/2013/ontarios-differentiation-policy-framework-ocufas-analysis/

Ozga, J. (2008). Governing knowledge: Research steering and research quality. European Educational Research Journal, 7(3), 261-272. https://doi.org/10.2304/ eerj.2008.7.3.261

Penner, R. (1994). Unionization, democracy, and the university. Interchange, 25(1), 49-53. https://doi.org/10.1007/BFo1447192

Rastin, S. (2000). Organizing tactics in a faculty unionization drive at a Canadian university. Labor Studies Journal, 25(2), 99-119.

Rhoades, G. (2017). Bread and roses, and quality too? A new faculty majority navigating the new academy. The Journal of Higher Education, 88(5), 645-671. https://doi.org/10 $.1080 / 00221546.2016 .1257310$

Ritzer, G., \& Walczak, D. (1986). Working, conflict and change (3rd ed.). Englewood Cliffs, NJ: Prentice-Hall.

Ross, S. (2011). Social unionism in hard times: Union-community coalition politics in the CAW Windsor's Manufacturing Matters campaign. Labour/Le Travail 68, 79-115. http://www.lltjournal.ca/index.php/llt/article/view/5646

Ross, S. (2012). Business unionism and social unionism in theory and practice. In S. Ross \& L. Savage (Eds.), Rethinking the politics of labour in Canada (pp. 33-46). Halifax, NS: Fernwood.

Savage, L., \& Webber, M. (2013). The politics of professional public sector unions. In L. Savage \& S. Ross (Eds.), Public sector unions in the age of austerity (pp. 114-125). Halifax, NS: Fernwood.

Savage, L., Webber, M., \& Butovsky, J. (2012). Organizing the ivory tower: The unionization of the Brock University Faculty Association. Labor Studies Journal, 37(3), 293-310. https://doi.org/10.1177/0160449X12463077

Shanahan, T., \& Jones, G. A. (2007). Shifting roles and approaches: Government coordination of postsecondary education in Canada. Higher Education Research and Development, 26(1), 31-43. 
Shore, C. (2010). "After neoliberalism"? The reform of New Zealand's university system. Learning and Teaching, 3(1), 1-31.

Slaughter, S., \& Rhoades, G. (2000). The neo-liberal university. New Labor Forum, 6, 73-79. https://www.jstor.org/stable/40342886

Stensaker, B., \& Harvey, L. (Eds.). (2011). Accountability in higher education: Global perspectives on trust and power. New York, NY: Routledge.

Tuchman, G. (2009). Wannabe U: Inside the corporate university. Chicago, IL: University of Chicago Press.

Turner, D. III. (2010). Qualitative interview design. The Qualitative Report, 15(3), 754-760. Retrieved from https://nsuworks.nova.edu/tqr/vol15/iss3/19

Waring, M. (2014). Human resources policies and the individualization of academic labour. In L. Gornall, C. Cook, L. Daunton, J. Salisbury, \& B. Thomas (Eds.), Academic working lives: Experience, practice and change (pp.102-109). London, UK: Bloomsbury.

Watson, C. (2011). Accountability, transparency, redundancy: Academic identities in an era of "excellence." British Educational Research Journal, 37(6), 955-971. https:// doi.org/10.1080/01411926.2010.508514

Webber, M., \& Acker. S. (2012, June). Academic frogs in the water? How Canadian academics understand accountability and their work in the contemporary university. Paper presented at the Academic Identities Conference, University of Auckland, NZ.

Webber, M., \& Acker, S. (2014, March). "I'm thinking about tenure from day one": Surveillance, subjectivity, and the tenure review process in Ontario universities. Paper presented at the Annual Meeting of the Comparative and International Education Society (CIES), Toronto, ON.

Willmott, H. (2003). Commercialising higher education in the UK: The state, industry and peer review. Studies in Higher Education, 28(2), 129-141. https://doi. org/10.1080/0307507032000058127

Zumeta, W. (2011). What does it mean to be accountable? Dimensions and implications of higher education's public accountability. Review of Higher Education, 35(1), 131-148. http://doi:10.1353/rhe.2011.0037

\section{Contact Information}

Michelle Webber

Department of Sociology

Brock University

mwebber@brocku.ca

Michelle Webber is a Professor in the Department of Sociology at Brock University. She publishes in the area of academic work. She is currently the president of the Brock University Faculty Association. 
Jonah Butovsky is an Associate Professor at Brock University and teaches quantitative methods and political sociology. Professor Butovsky has published articles on the politics of faculty unions, migrant agricultural workers in the Niagara Region, and a series of papers on Marx's theory of the falling rate of profit. Most recently he completed a study (with several others) on precarious work in Niagara called Uncertain Jobs, Certain Impacts: Employment Precarity in Niagara (Poverty and Employment Precarity in Niagara Research Group, April 2018). 